\title{
Integrated Law Enforcement to Fight Environmental Crime Towards Good Environmental Governance
}

\author{
Riska Andi Fitriono \\ \{riskaandi86@gmail.com\} \\ Universitas Sebelas Maret, Jl. Ir. Sutami No.36A, Kota Surakarta, Jawa Tengah 57126, Indonesia

\begin{abstract}
Environmental crime has brought a significant impact on human life, and it causes the decline of environmental quality which has resulted in a wide range of endemic diseases. It also afflicts almost all regions in Indonesia, such as an outbreak of dengue fever, vomiting, and diarrhea, lung, and others. The failure of the environmental criminal law enforcement is caused by the absence of synchronization of the criminal justice system such as police, prosecutors, courts, and correctional services. The method used in this research is socio-legal research. The research results showed that there was no integrated law enforcement done by law enforcers regarding environmental crime. Of course, it was unable to solve various cases of environmental crime done by corporations. Integrated law enforcement should be formulated in tackling environmental crime in order to achieve good environmental governance and to overcome the weaknesses of fighting environmental criminal cases. It is necessary to conduct a new integrated approach. In 2007, the study was developed by encouraging the use of instruments of anti-corruption and anti-money laundering through the study of integrated law enforcement. The law enforcement approach is called as Integrated Law Enforcement Approach (ILEA). This approach cannot be made without its devices and the relevant components. A device is a tool that is necessary in order to implement an integrated approach to law enforcement, while component refers to institutions that play a role in implementing this ILEA approach.
\end{abstract}

Keywords: Integrated Legal System, Law Enforcement, Environmental Crime, Good Governance

\section{Introduction}

The emergence of environmental cases that occurred in various parts of the world cannot be separated from the attitude and behavior of human exploitation on the environment. Attitudes and behaviors are nothing but an implication of the firm view of anthropocentrism, which always puts humans and its importance as the center of everything. Human detainees are considered the most decisive in the ecosystem so that they could do anything about the environment, albeit in ways that damage the environment. As a result, the environmental crisis occurs, like the crisis of water, clean air, wildlife extinction, etc. The crisis has also become one of the "contributor" of severe global crisis[1].

Law enforcement on environmental cases is not getting better, but it tends to dilapidate. Various environmental cases cannot be handled comprehensively based on ecological interest[2]. Administration officials who should have been at the forefront of law enforcement have not been able to do the best action for the benefits of the environment. The weak law rules and lack of ability, coupled with corrupt behaviors, are the main obstacles.

At the macro level, the failure of the enforcement of the criminal law can also be seen from some significant cases, such as illegal logging cases in 2007, in which the police have processed 985 cases in Indonesia involving 1229 suspects. In 2008, the police also arrested 
500 people including the three bosses, but unfortunately, the case was not processed before the court on the grounds of insufficient evidence, the existence of mafia, political interference, and power. The criminals were indeed done by a large group and replete by internal and external people. They are often called as a timber baron. They have full powers, including top officials in government agencies, such as the Head of Mandailing, Regent Mandailing Natal, which has been a suspect for illegal logging by Adelin Lis in Mandailing Sumatra. There are also many cases of illegal logging in Kalimantan and Papua. One of them is the pollution of Buyat Bay by Newmont Minahasa Raya. The handling of cases reflects the unsuccessful environmental criminal law enforcement (Masrudi Muchtar, 2015). This can also be seen from the PROPER Secretariat data. From 2010 to 2011, the PROPER assessment found that from 33 food and beverage companies, only $42 \%$ of it obey environmental regulations, while the rest are rated red.

Furthermore, the number 42 Hospital showed that $33 \%$ are rated blue, while the other $64 \%$ are rated red and black. Meanwhile, the number of 44 hotels overseen only $11 \%$ are rated blue, while the rest are rated red. The Proper Secretariat noted that most violations of environmental regulations related to the unavailability of hotels to provide temporary shelter for hazardous wastes generated from wastewater treatment plants.

Furthermore, based on the comparison between 2010-2011 and the 2011-2012 periods, the Proper ratings showed that 94 out of 330 companies had received the red rating, while the other 37 companies received the blue rating, and 1 got the black rating in 2010-2011. Thus, 79 companies ranked in the period 2011-2012, 32 companies are getting a red rating and one blue company rating in the previous year. This means that as many as 37 companies are down from blue to red, and one company goes from blue to black. Besides, 131 companies have two consecutive periods of disobedience[3]

Such condition is very apprehensive because it is not by the wishes of the people to immediately create law enforcement in order to create clean environmental conditions, which are free from pollution and environmental destruction. Thus, we need to find the cause why many environmental cases conducted by large companies, which have made pollution and harm for the environment and society, are not processed at court.

The failure of the criminal law enforcement against environmental crime prevention is due to the lack of synchronization and disharmony on a legal structure, legal culture, and legal substance of the criminal justice system; such as police, prosecutors, courts, and correctional services. Therefore, the government must integrate perceptions, beliefs, responses, concepts, and opinions of the people and law enforcers to fight environmental crime as an extraordinary crime because it has a tremendous impact not only the lives of humans but also the destruction of nature. Therefore, it must be taken seriously by having a strong will and being united in a single criminal justice system to save the world and make prosperity[4]. A one-stop court is very significant to address the problem of environmental criminal law enforcement in the field of environment. It means that all the existing sub-systems in the criminal justice system such as police, prosecutors, judiciary, advocates, and prisons are under one supervision of the Ministry of Environment[5].

\section{Methodology}

This research method is empirical or non-doctrinal. This kind of research method views law not only from the perspective of the legislation but also its implementation or law in action. Therefore, the required data are primary and secondary. 


\section{Findings}

\subsection{The Existing Condition of The Environmental Criminal Law Enforcement}

Satjipto Rahardjo said that law enforcement is an attempt to realize ideas and concepts into reality[6]. Law enforcement is a process to realize the desires of the law to become a reality. Desires are law thoughts of the lawmaking body for making a law.In principle, law enforcement is done by the efforts of preventive and repressive nature. The preventive effort is a series of actions as deterrence of law violations, while repressive law enforcement is intended to crack down upon the violation[5].

Police Agency, as a subsystem of the criminal justice system, is the front guard or the cutting edge for the disclosure of criminal cases in the field of environment. The success or failure of disclosure of environmental crime cases in Indonesia depends on foresight, skill, ability, and commitment of the investigators. The preventive task is carried out by the police and assisted by the community. If prevention efforts fail, then the police should take repressive actions.

When you see a blurred portrait of handling environmental crime in Indonesia, the subsystem Police have significantly contributed to the weak enforcement of the environmental criminal law. This is a structural problem. The police do not have a specific policy in the cases of environmental crime and have no special division with adequate human resources to address environmental issues, such as division of corruption matter, drug, money laundering, etc.

There is an overlapping of authority in Law No. 32 of 2009 on the Protection and Management of the Environment, in particular, in handling the environmental crime. The Civil Service Investigator (called as PPNS) is no longer limited to coordinate, but it has the authority to prosecute. The arrest, detention, and investigation are then submitted to the public prosecutor in coordination with the police. This provision was challenged and protested against being a cause of the poor performance of the police in revealing environmental cases over the years. If these provisions are not mutually understood then there will be overlapping authority, and the seizure of land as a result of the investigation will, in turn, lead to a dispute between the police and the PPNS.

Also, the Attorney Institution acts as a leading institution in uncovering environmental crime cases. As a leading institution, the prosecutor has a formidable task to reveal a case. Of course, it depends on the finesse and expertise of the prosecutor in making claims. For example, the disclosure of a case depends on the prosecutor institution. Unfortunately, the institution seems very slow or even unready to handle environmental cases because it does require specific and inter-disciplinary knowledge on environment. It is proven in the failure of filing claim in handling environmental cases for the high-class businessman. The incompetence and inaction of this institution may be found in Law No. 16 of 2004 on the Prosecutor of the Republic of Indonesia. It has given a broad authority of the prosecutor as representative of the government. This is understandable because the constitutional structure of the prosecutor is part of the government, it was representing the government in filing the case before the court against illegal actions, so, naturally, the institution is perceived as a tool of the government. As an institution that stands on two interests, on the one hand, it acts as an advocate of government, but on the other hand, it upholds the law of justice. So ambiguity influences their duty to struggle law and justice. Therefore, it is necessary for rethinking the independence of the prosecutor in carrying out the duties. The prosecutor should become an independent institution that is free from interference. 


\subsection{Formulation of Integrated Law Enforcement In Tackling Environmental Crime}

To address various weaknesses in the handling of criminal cases in the field of forestry requires a new and integrated approach. This law enforcement approach is called the Integrated Law Enforcement Approach (ILEA) or the Integrated Law Enforcement Approach. This approach cannot be appropriately made without the existence of relevant tools and components. The tool is needed to implement an integrated law enforcement approach, while the component refers to the institutions that play a role in implementing this ILEA approach, which can also be called as law enforcement in a holistic perspective.

In a holistic perspective, the law does not contain merely rules with rigid procedures, and it has to pay attention to the social aspects, including environmental matters. Law cannot be separated by social dynamic. Law is regarded as a whole with all of its elements, including law enforcement. It is intended to keep ecological sustainability rather than other interests. According to Fritjof Capra, the perspective is an approach to see the world as an integrated system rather than a collection of separated parts[7].

Integrated law enforcement requires the implementation of some basic principles. First, the three instruments of environmental law (administrative, civil, and criminal) are not a separate alternative. There is a dichotomy, but they can be applied simultaneously and synergistically with one another. Therefore, it requires synergic cooperation between law enforcement fellows such as investigators, prosecutors, judges, and administration officials. Adelin Lis is an example of the case. Although criminally PN Medan had acquitted him, it is still possible to do an extraordinary legal remedy (appeal), as well as civil suits or the application of administrative sanctions, such as revocation of forest concessions. This is the core of the basic principles of the first holistic, which requires law enforcement as a whole by employing all legal instruments in comprehensive and synergistic cooperation of law enforcement. Environmental law enforcement is not solely through criminal law, but it may also apply other legal means, namely civil law and administrative law. Even the means of administrative law can become the frontline in the enforcement of environmental law. If the environmental administrative law is applied and implemented correctly and consistently, inevitably, the damage or environmental contamination will not occur. At least, the damage and environmental pollution can be reduced as much as possible.

Second, it requires a comprehensive understanding of law enforcement (administrative officials, police, prosecutors, judges, and lawyers) on the substance of environmental law. Law enforcement is less familiar with the characters. Training for police, prosecutors, and judges, who deal specifically with environmental causes, is indispensable.

Third, environment and state loss as a result of integrated law enforcement approach can be minimized by using laws other than the environmental law, such as Law of Anti-Corruption and Anti-Money laundering which are strictly related to the number of state losses caused by the practices of forestry crimes. Therefore, calculation or estimation of the cost of environmental damage and the number of state losses due to deforestation and illegal logging becomes essential. It is estimated that the cost of environmental damage could be done by calculating the costs of ecological damage, economic losses, and costs of environmental restoration[8].

The calculation of the ecological damage is done indirectly by the destruction of the environment due to the destruction of forests and land. These losses are calculated by the cost of making the reservoir or dam, the cost of water regulation, the cost of controlling erosion and runoff, the cost of soil formation, the cost of recycling nutrients, the cost of decomposing waste, the cost of biodiversity, the cost of genetic resources, as well as the cost of the release of carbon per hectare. Based on the explanation of Article 32 of Law No. 31 of 1999 on the 
Eradication of Corruption (from now on Law on Corruption), the number of state losses are based on the findings of the competent agency (BPK) on the results of the auditing accountant designated by the investigator[9].

\section{Conclusion}

The current Environmental Law Enforcement reflects the failure to handle environmental crime due to zero integrated law enforcement. Each subsystem works individually. Therefore, it is significant to establish integrated environmental law enforcement.

The Integrated Law Enforcement is designed to tackle Environmental Criminal Law cases effectively in order to achieve good environmental governance by using legal and institutional framework related to the environmental field. This approach includes the enhancements of law enforcement officers and its institution to protect the environment.

\section{References}

[1] S Vijay Anand, “Open Access Scientefic Reoprts,” Open Access Sci. Reports, 2013.

[2] V. Maddali, G. A. Tularam, and P. Glynn, "Economic and Time-Sensitive Issues Surrounding CCS: A Policy Analysis,” Environ. Sci. Technol., 2015.

[3] P. M. Cozens, G. Saville, and D. Hillier, "Crime prevention through environmental design (CPTED): A review and modern bibliography," Prop. Manag., 2005.

[4] P. Cozens and T. Love, "A Review and Current Status of Crime Prevention through Environmental Design (CPTED),” J. Plan. Lit., 2015.

[5] A. Dura and A. Belishta, "The European union legislation in the fields of environmental crime: The protection of the victims from such crimes," Mediterr. J. Soc. Sci., 2013.

[6] S. Rahardjo, "Hukum Progresif: Hukum yang Membebaskan," Huk. Progresif, 2011.

[7] DNN and F. Capra, "The Web of Life: A New Scientific Understanding of Living Systems," Colon. Waterbirds, 1997.

[8] H. A. Regier, J. R. Coon, and J. A. Jackson, "Towards a balance between responsibilities and rights to the ecosystemic goods and services of our Great Lakes St. Lawrence River basin," J. Great Lakes Res., vol. 41, no. S1, pp. 8-11, 2015.

[9] S. R. Ika and N. A. Mohd Ghazali, "Audit committee effectiveness and timeliness of reporting: Indonesian evidence,” Manag. Audit. J., 2012. 